\title{
PALLISTER-KILLIAN SYNDROME: CYTOGENETIC AND BIOCHEMICAL STUDIES
}

\author{
Kouji Narahara, ${ }^{1}$ Yoshiharu Wakita, ${ }^{1}$ Kiyoshi KikKawa, ${ }^{1}$ \\ Kei Hiramoto, ${ }^{1}$ Hiroshi Namba, ${ }^{1}$ Masae Murakami, ${ }^{1}$ \\ Ryozou KASAI, ${ }^{2}$ and Hiroshi KImoto ${ }^{1}$ \\ ${ }^{1}$ Department of Pediatrics, Okayama University School of Medicine, \\ Okayama 700, Japan \\ ${ }^{2}$ Asahigawa Jidoin Hospital for Handicapped Children, \\ Okayama 703, Japan
}

\begin{abstract}
Summary Pallister-Killian syndrome is characterized by specific dysmorphic features and tissue-limited mosaicism for tetrasomy $12 \mathrm{p}$. We describe an additional case of a stillborn neonate, who had not only the specific craniofacial features seen in the syndrome but also various internal malformations. Cytogenetic study showed that an extra F-like chromosome was found in $43 \%$ of lymphocytes and in $90 \%$ of fibroblasts. The high resolution G-banded pattern of the extra chromosome was consistent with an interpretation of an $\mathrm{i}(12 \mathrm{p})$. The diagnosis of tetrasomy $12 \mathrm{p}$ was further confirmed by four-fold gene dosage effects in fibroblasts for GAPD and LDH-B, whose locus was both assigned to the 12p. The proportion of tetrasomic cells in fibroblasts decreased remarkably during long-term cultures. These results suggest that the tissue specific mosaicism in the syndrome is not simply a result of preferential selection against lymphocytes carrying the marker but may be related to the time of mosaic formation as well as the somatic selection of different intensity in different tissues.
\end{abstract}

\section{INTRODUCTION}

Pallister-Killian syndrome is an eponymous designation honoring the initial discoverers (Pallister et al., 1977; Teschler-Nicola and Killian, 1981). It is a rare clinical entity based on a tissue-limited mosaicism for tetrasomy 12p: an isochromosome of chromosome $12 p$ [i(12p)] is found in a high percentage of skin fibroblasts but virtually absent from blood lymphocytes. The similarity of banding patterns between the $12 p$ and $21 q$ has sometimes led to a misinterpretation of $i(12 p)$ as $i(21 q)$

Received March 28, 1988; revised version received May 31, 1988; Accepted May 31, 1988 
(Fryns et al., 1982; Hunter et al., 1982; Kwee et al., 1984; Lopes et al., 1985). More than two dozen of cases have so far been reported (Reynolds et al., 1987). Patients with Pallister-Kilian syndrome invariably show characteristic clinical features, including normal intrauterine growth, severe mental retardation, pigmentary dysplasia, aberrant scalp hair pattern in infancy and coarse face (Buyse and Korf, 1983). The occurrence of serious internal malformations is rare, and the life prognosis is usually excellent. We describe here another case of a stillborn neonate associated with various internal malformations, where tetrasomy $12 \mathrm{p}$ mosaicism were confirmed by cytogenetic and gene dosage studies. The observation of $i(12 p)$ in a hitherto unreportedly high proportion of lymphocytes and the substantial reduction in percentages of tetrasomic cells during long-term cultures of fibroblasts provides an important insight into the cytogenetic mechanism of the distinctive pattern of chromosome abnormality in the syndrome.

\section{CASE REPORT}

The patient, a male infant with 32 weeks' gestational age, was a product of the fourth pregnancy of unrelated 34-year-old parents, which was complicated by polyhydramnios ( $c a .5,000 \mathrm{ml}$ of amniotic fluid) and premature onset of labor. The death had occurred during the delivery. There was no family history of mental

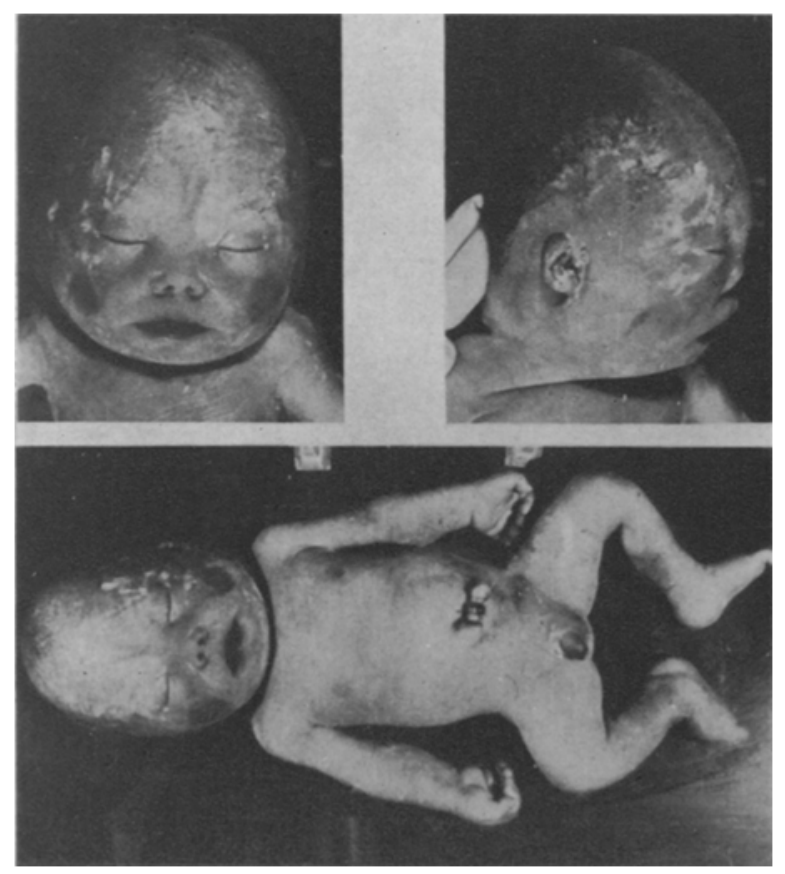

Fig. 1. The patient at autopsy. 
retardation or multiple congenital anomalies. The first and third pregnancies yielded two normal siblings, while the second pregnancy ended in a first-trimester spontaneous abortion. The patient was appropriate for the gestational age $(2,290 \mathrm{~g}$ in weight and $42.0 \mathrm{~cm}$ in height). Scalp hairs, thin and hypopigmented, were absent or very sparse in the frontal and bitemporal regions. The head was brachycephalic with a prominent forehead. Facial features consisted of microphthalmia with hypertelorism and epicanthal folds, short upturned nose with broad alae nasi and flat nasal bridge, long philtrum, downturned mouth and full cheeks (Fig. 1). Cleft palate and hypoplasia of ears with low settings were also noticed. The neck was very short with redundant skin. There was shortening of the humeri, broad hands with stubby fingers and postaxial polydactyly on the left foot. Congenital lymphedema was present on the eyelids, the neck and the backs of hands and feet. There was no pigmentary dysplasia of skin. Penis was small, and testes were undescended bilaterally. There was also a sacral dimple and an imperforate anus. Additional findings at autopsy included the left diaphragmatic agenesis with associated herniation of abdominal content into the left hemithorax, defect of the pericardium, the rightward displacement of the heart, juxtaductal coarctation of the aorta, profound hypoplasia of the left lung, accessory left lobe of the liver, common mesenterium and cerebral atrophy with dilated lateral ventricles.

\section{CYTOGENETIC STUDY}

Cytogenetic study was performed on a blood sample obtained by cardiac paracentesis at autopsy. Fibroblast cultures were also established from a skin sample taken from the anterior chest. According to the method of Ikeuchi and Sasaki (1979), phytohemagglutinin stimulated lymphocytes were treated with ethidium bromide $2 \mathrm{hr}$ before harvest. Chromosomes were analyzed after GTG-, CBGand QFQ-bandings and Ag-I staining. Table 1 shows the results of cytogenetic studies. Analysis of blood lymphocytes revealed an extra F-like chromosome in 51 of $119(42.9 \%)$ cells examined. The marker chromosome was found to possess a symmetric structure on QFQ-banding and a single centromeric heterochromatin

Table 1. Results of cytogenetic studies.

\begin{tabular}{ccccc}
\hline & $46, \mathrm{XY}$ & $47, \mathrm{XY},+\mathrm{i}(12 \mathrm{p})$ & $\begin{array}{c}48, \mathrm{XY}+\mathrm{i}(12 \mathrm{p}) \\
\text {-mar }^{\mathrm{a}}\end{array}$ & Total \\
\hline $\begin{array}{c}\text { Blood lymphocytes } \\
\text { Skin fibroblasts }\end{array}$ & $68(57.1 \%)$ & $51(42.9 \%)$ & 0 & $119(100 \%)$ \\
3rd passage & $9(9.6 \%)$ & $84(89.4 \%)$ & $1(1.0 \%)$ & $94(100 \%)$ \\
5th passage & $4(10.3 \%)$ & $35(89.7 \%)$ & $0(0 \%)$ & $39(100 \%)$ \\
11th passage & $12(34.3 \%)$ & $23(65.7 \%)$ & $0(0 \%)$ & $35(100 \%)$ \\
16th passage & $18(47.4 \%)$ & $20(52.6 \%)$ & $0(0 \%)$ & $38(100 \%)$ \\
\hline
\end{tabular}

a A minute chromosome of unknown origin. 


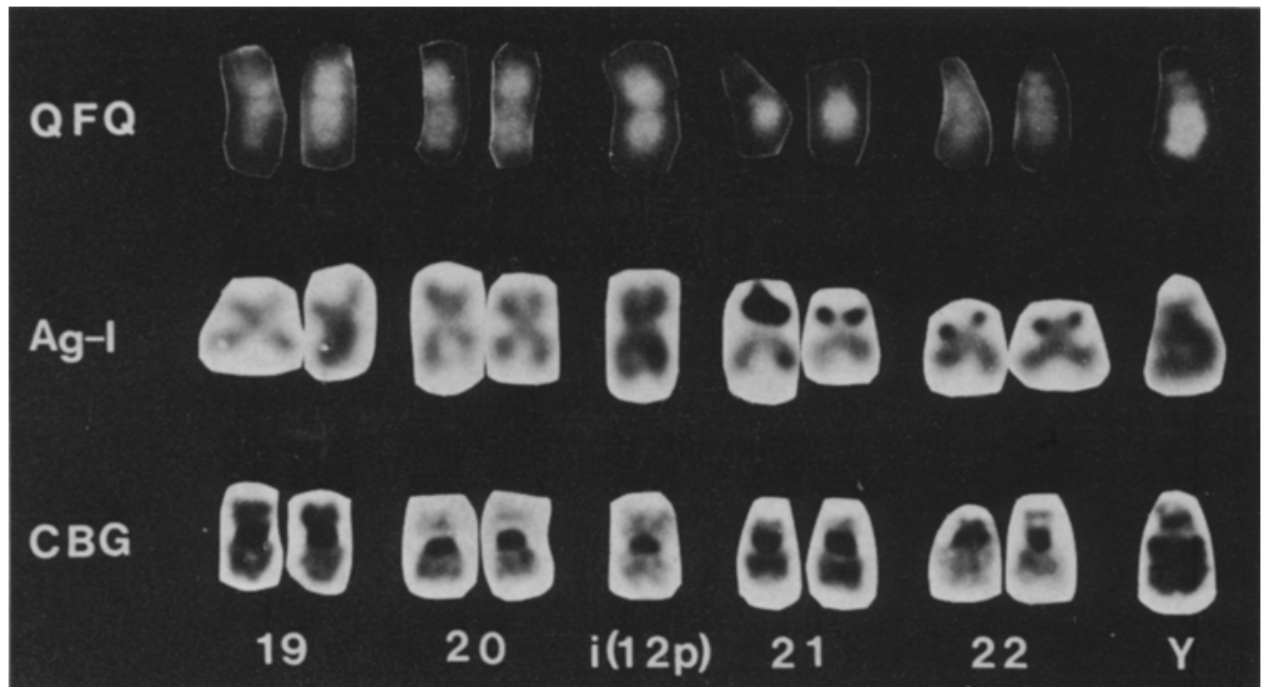

Fig. 2. Partial karyotypes of the patient (QFQ-banding, Ag-I staining and CBG-banding). The extra chromosome, i(12p), is shown in the middle of each row.

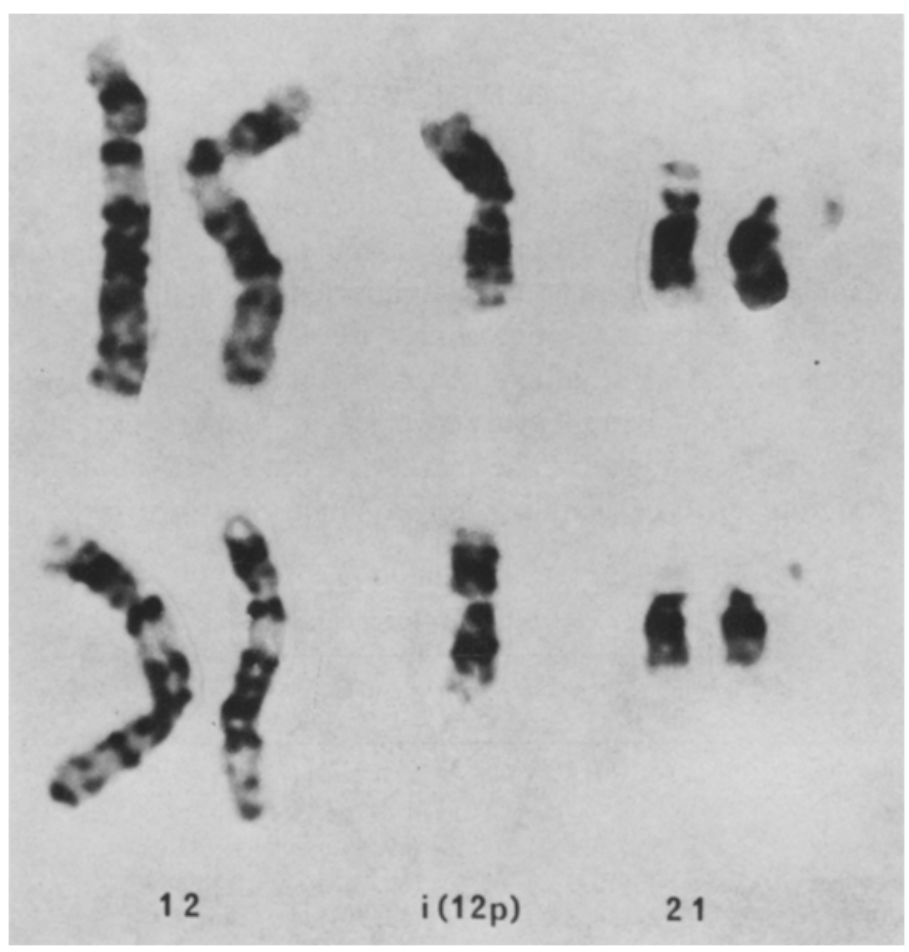

Fig. 3. High-resolution G-banding analysis of the extra chromosome. The banding pattern was compatible with an interpretation of $i(12 p)$. 
on CBG-banding but no NOR-region on Ag-I staining (Fig. 2). The high-resolution G-banding pattern was compatible with an interpretation of i(12p) (Fig. 3). The same marker chromosome was present in 120 of $133(90.2 \%)$ skin fibroblasts analyzed at early passages (the 3 rd and 5 th passages), but after long-term cultures the proportion of the abnormal cell line decreased significantly. The G-banded karyotypes of both parents were completely normal.

\section{BIOCHEMICAL STUDIES}

In order to confirm biochemically the origin of the extra chromosome, we studied gene dosage effects for glyceraldehyde-3-phosphate dehydrogenase (GAPD), lactate dehydrogenase component $\mathrm{B}$ (LDH-B) and soluble superoxide dismutase (SOD1). In Human Gene Mapping 8, GAPD, LDH-B and SOD1 have been assigned to $12 \mathrm{p} 13.1 \rightarrow \mathrm{p} 13.32,12 \mathrm{p} 12.1 \rightarrow \mathrm{p} 12.2$ and $21 \mathrm{q} 22.1$, respectively. These enzyme activities were estimated on cultured fibroblasts from the patient at the 3 rd and 5th passages, using the method of Jaworek et al., 1974, for GAPD, that of Wroblewski and La Due (1955) for LDH and that of McCord and Fridovich (1969) for SOD. As described by Homer et al., 1969, LDH isoenzymes were separated on cellulose acetate. They were stained with nitro blue tetrazolium and quantified by a densitometer (Hiranuma, HAD-501). Fibroblasts harvested on near confluence were lysed by freezing and thawing thrice in distilled water containing $20 \mathrm{~mm} 2$ mercaptoethanol. Controls consisted of cultured skin fibroblasts from 8 individuals with normal karyotypes, ranging from 2 months to 7 years in age. Proteins were assayed according to the method of Lowry et al., 1951.

Results of enzyme assays are shown in Table 2. GAPD activity in fibroblasts from the patient was increased 1.77 times as much as in those from the normal controls, while LDH and SOD activities were within the normal ranges. The increment of the GAPD value in the patient was in good agreement with four-fold gene dosages for GAPD in $90 \%$ of cells tested, thus demonstrating that the extra chromosome

Table 2. Results of gene dosage studies on fibroblasts.

\begin{tabular}{llll} 
& \multicolumn{1}{c}{ GAPD $^{\mathrm{a}}$} & \multicolumn{1}{c}{$\mathrm{LDH}^{\mathrm{a}}$} & \multicolumn{1}{c}{ SOD $^{\mathrm{b}}$} \\
\hline Patient & $\begin{array}{l}7.69 \mathrm{U} / \mathrm{mg} \text { protein } \\
(\mathrm{n}=2)\end{array}$ & $\begin{array}{l}4.80 \mathrm{U} / \mathrm{mg} \text { protein } \\
(\mathrm{n}=2)\end{array}$ & $\begin{array}{l}15.4 \mathrm{U} / \mathrm{mg} \text { protein } \\
(\mathrm{n}=2)\end{array}$ \\
$\begin{array}{l}4.34 \pm 0.78 \mathrm{U} / \mathrm{mg} \\
\text { Normal controls }\end{array}$ & $\begin{array}{l}4.75 \pm 0.69 \mathrm{U} / \mathrm{mg} \\
\text { protein }(\mathrm{n}=8)\end{array}$ & $\begin{array}{l}14.7 \pm 2.9 \mathrm{U} / \mathrm{mg} \\
\text { protein }(\mathrm{n}=5)\end{array}$ \\
$\begin{array}{l}\text { Ratio of patient } \\
\text { to normal value }\end{array}$ & 1.77 & 1.01 & 1.05 \\
\hline
\end{tabular}

${ }^{\text {a }}$ One unit is expressed in $\mu \mathrm{m} / \mathrm{min}$. ${ }^{b}$ One unit is defined as an activity inhibiting $50 \%$ of reduction of cytochrome $c$ in a SOD-free reaction system. 
Table 3. Results of densitometric assays of LDH isozymes in fibroblasts.

\begin{tabular}{lrrrrr}
\hline & Patient & $\begin{array}{c}\text { Control } \\
1\end{array}$ & $\begin{array}{c}\text { Control } \\
2\end{array}$ & $\begin{array}{c}\text { Control } \\
3\end{array}$ & $\begin{array}{c}\text { Mean of } \\
\text { controls }\end{array}$ \\
\hline $\begin{array}{l}\text { LDH isozymes } \\
\quad\end{array}$ & & & & & \\
$\mathrm{B}_{4}$ & $0 \%$ & $0 \%$ & $0 \%$ & $0 \%$ & $0 \%$ \\
$\mathrm{~A}_{1} \mathrm{~B}_{3}$ & $5.9 \%$ & $1.5 \%$ & $1.4 \%$ & $1.2 \%$ & $1.4 \%$ \\
$\mathrm{~A}_{2} \mathrm{~B}_{2}$ & $29.5 \%$ & $20.9 \%$ & $19.1 \%$ & $21.7 \%$ & $20.6 \%$ \\
$\mathrm{~A}_{3} \mathrm{~B}_{1}$ & $37.4 \%$ & $41.2 \%$ & $38.5 \%$ & $35.9 \%$ & $38.5 \%$ \\
$\quad \mathrm{~A}_{4}$ & $27.2 \%$ & $36.4 \%$ & $41.0 \%$ & $41.2 \%$ & $39.5 \%$ \\
$\begin{array}{l}\text { LDH total activity } \\
(\mathrm{U} / \mathrm{mg} \text { protein) }\end{array}$ & 4.80 & 4.86 & 4.25 & 5.49 & 4.87 \\
\hline
\end{tabular}

${ }^{a}$ A mean of four densitometric assays performed in each subject.

is actually an $\mathrm{i}(12 \mathrm{p})$. LDH electrophoresis disclosed more prominent staining of $A_{1} B_{3}$ and $A_{2} B_{2}$ isozymes but less distinctive staining of an $A_{4}$ isozyme in the patient than seen in the normal controls. The visual impression of the LDH zymograms was substantiated by the densitometric assays (Table 3). If the quantity of LDH component $\mathrm{B}$ and $\mathrm{A}$ in cells is denoted as $\mathrm{x}$ and $1-\mathrm{x}$ for controls and $\mathrm{y}$ and $1-\mathrm{y}$ for the patient, the ratios $y / x$ and $1-y / 1-x$ will represent a rough estimate of gene dosage for LDH-B and LDH-A in the patient, respectively. Solving the equations set up between densitometric data of isozymes $A_{3} B_{1}$ and $A_{2} B_{2}, A_{3} B_{1}$ and $A_{1} B_{3}$, and $A_{1} B_{3}$ and $A_{2} B_{2}$ gave $y / x=1.75,1.72$ and 1.87 , and $1-y / 1-x=0.90,0.83$ and 0.64 , respectively. The ratios also supported our cytogenetic interpretation.

\section{DISCUSSION}

The present case was found to have not only the specific craniofacial features seen in Pallister-Killian syndrome but various internal malformations which have been rarely reported in the previous surviving cases. It should be noted that tetrasomy $12 \mathrm{p}$ mosaicism has been increasingly ascertained at birth or by prenatal diagnosis. Review of autopsy findings in 8 such cases (Gilgenkrantz et al., 1985; Lopes et al., 1985; Hiraishi et al., 1987; Pauli et al., 1987; Reynolds et al., 1987; Steinbach and Rehder, 1987; Warburton et al., 1987) showed that internal malformations are not at all rare and lung hypoplasia is a common pathological finding (Table 4). This type of malformation may explain why neonatal asphyxia is frequently associated with Pallister-Killian syndrome. Interestingly, 3 cases which did not survive birth and 2 prenatally diagnosed cases were also noted to have massive diaphragmatic hernias. As indicated by Kawashima (1987), the rhizomelic type micromelia involving the humeri has to be regarded as the specific phenotypic features for this syndrome in early infancy. 
Table 4. Pathological findings in cases ${ }^{a}$ with tetrasomy $12 \mathrm{p}$ mosaicism ascertained at birth or prenatally.

Case 1 Case 2 Case 3 Case 4 Case 5 Case 6 Case 7 Case $8 \begin{gathered}\text { Present } \\ \text { case }\end{gathered}$

\begin{tabular}{lccccccccc}
\hline Prenatal diagnosis & + & + & & + & + & & + & + & \\
Neonatal death & & & + & & & + & & & + \\
Polyhydramnios & + & - & - & + & - & + & - & ND & + \\
Gestational age in weeks & 29 & ND & 31 & 22 & 24 & 38 & 20 & 19 & 32 \\
Body weight in grams & 1,920 & ND & 1,590 & 825 & 368 & 3,100 & ND & 475 & 2,290 \\
Diaphragmatic hernia & - & + & + & - & - & + & + & ND & + \\
Lung hypoplasia & + & + & + & + & + & + & + & ND & + \\
Cardiac defect & + & - & - & ND & + & - & ND & ND & + \\
Intestinal malformations & - & - & - & + & + & - & + & ND & + \\
Imperforate anus & - & - & + & + & - & - & ND & ND & + \\
Urinary tract malformations & - & - & + & - & + & ND & ND & + & - \\
Rhizomelic type micromelia & + & ND & + & ND & + & ND & ND & ND & + \\
Brain malformations & + & ND & ND & ND & + & ND & ND & + & + \\
\hline
\end{tabular}

a Case 1: Gilgenkrantz et al., 1985; Case 2: Lopes et al., 1985; Case 3: Pauli et al., 1987; Case 4: Reynolds et al., 1987; Case 5: Steinbach and Rehder, 1987; Cases 6 and 7: Warburton et al., 1987; and Case 8: Hiraishi et al., 1987. b Not described.

The discrepancy in cytogenetic findings between fibroblasts and lymphocytes has been believed to be a hallmark of Pallister-Killian syndrome. The exact mechanism by which the tissue specific mosaicism for i(12p) occurs is unclear. The most plausible hypothesis proposed for the formation of $\mathrm{i}(12 \mathrm{p})$ is a meiotic error with concurrent isochromosome formation due to a centromere misdivision involving a desynaptic univalent and nondisjunction (Van Dyke et al., 1987). The isochromosome itself is also prone to malsegregate during the early cleavage mitosis, yielding two new cell lines with a chromosome constitution of 46 and $48,+i(12 p),+i(12 p)$ in addition to that with $47,+i(12 p)$. Some selective process is presumed to lead to the eventual distinctive cytogenetic pattern.

The tissue-limited mosaicism, however, is not always consistent in the syndrome. In a number of cases (Lopes et al., 1985; Raffel et al., 1986; Pauli et al., 1987; Reynolds et al., 1987; Warburton et al., 1987), i(12p) was found in 10-20\% of blood lymphocytes. The percentage of tetrasomy $12 \mathrm{p}$ in lymphocytes in our case $(43 \%)$ was even higher. Furthermore, as indicated in two other reported cases (Peltomäki et al., 1987; Warburton et al., 1987), the proportion of the abnormal cell line in fibroblasts decreased substantially during long-term cultures. These findings suggest that the occurrence of the tissue specific mosaicism in the syndrome is not simply a result of preferential selection against lymphocytes carrying the marker (Hunter et al., 1985) but may be related to the time of mosaic formation as well as the somatic 
selection of different intensity in different tissues. Perhaps, the mitotic nondisjunction occurs between the first cleavage division and early embryonal stage. The case misinterpreted as hexasomy 21 mosaicism (Ketupanya et al., 1984) and ours may be the extreme examples concerning the time of mosaic formation.

The diagnosis of tetrasomy $12 \mathrm{p}$ in the present case was also supported by the four-fold gene dosage effects for GAPD and LDH-B in cultured fibroblasts. Biochemical confirmation of tetrasomy $12 p$ has previously been made by the use of LDH-B determinations (Vine et al., 1984; Gilgenkrantz et al., 1985; Kelly et al., 1985; Steinbach and Rehder, 1987; and Warburton et al., 1987). On electrophoresis of $\mathrm{LDH}$, extracts of fibroblasts containing an $\mathrm{i}(12 \mathrm{p})$ in nearly all cells were shown to produce a strong $A_{2} B_{2}$ band and a distinct $A_{1} B_{3}$ band. In those containing less than $30 \%$ of the tetrasomic cells, however, an $A_{1} B_{3}$ isozyme is barely recognized, limiting the sensitivity of LDH-B determinations (Warburton et al., 1987). The tetrameric structure of LDH and the reduced expression of LDH-B gene products in fibroblasts may be responsible for the inaccuracy of LDH-B determinations. We wish to emphasize that the assay of GAPD is simpler and more reliable in the biochemical confirmation of tetrasomy $12 \mathrm{p}$.

Recently, tetrasomy $12 \mathrm{p}$ has been proven by Southern blot hybridizations using a KRAS 2 gene probe localized in the 12p (Peltomäki et al., 1987). Though this study failed to determine when $\mathrm{i}(12 \mathrm{p})$ had been formed or from which parent the isochromosome had originated, such a methodological approach may be promising to solve the problems if an fully informative restriction fragment length polymorphism of a gene localized in the $12 p$ is available.

\section{REFERENCES}

Buyse, M.L. and Korf, B.R. 1983. "Killian syndrome," Pallister mosaic syndrome, or mosaic tetrasomy 12p?-An analysis. J. Clin. Dysmorphol. 1: 2-5.

Fryns, J.P., Petit, P., Vinken, L., Geutjens, J., Marien, J., and van den Berghe, H. 1982. Mosaic tetrasomy 21 in severe mental handicap. Eur. J. Pediatr. 139: 87-89.

Gilgenkrantz, S., Droulle, P., Schweitzer, M., Foliquet, B., Chadefaux, B., Lombard, M., Chery, M., and Prieur, M. 1985. Mosaic tetrasomy 12p. Clin. Genet. 28: 495-502.

Hiraishi, Y., Tamura, S., Kimura, Y., Takata, M., Hatanaka, S., Kusunoki, I., Natori, M., Kobayashi, T., Iizuka, R., and Yanagi, Y. 1987. A case with Pallister mosaic syndrome encountered in prenatal diagnosis (the author's translation). Abstracts (C 24) in the 32nd Annual Meeting of the Japan Society of Human Genetics (1987).

Homer, G.M., Yott, B., and Lim, J.G. 1969. Demonstration of lactate dehydrogenase isoenzyme on cellulose acetate. Am. J. Clin. Pathol. 51: 287-292.

Hunter, A.G.W., Clifford, B., Speevak, M., and MacMurray, S.B. 1982. Mosaic tetrasomy 21 in a liveborn male infant. Clin. Genet. 21 : 228-232.

Hunter, A.G.W., Clifford, B., and Cox, D.M. 1985. The characteristic physiognomy and tissue specific karyotype distribution in the Pallister-Killian syndrome. Clin. Genet. 28: 47-53.

Ikeuchi, T. and Sasaki, M. 1979. Accumulation of early mitotic cells in ethidium bromide-treated human lymphocytes cultures. Proc. Jpn. Acad. 55: 15-18. 
Jaworek, D., Gruber, W., and Bergmeyer, H.U. 1974. Adenosin-5'-triphosphate: Determination with 3-phosphoglycerate kinase. In Methods of Enzymatic Analysis, Bergmeyer, H.U., ed., Academic Press, New York, pp. 2097-2101.

Kawashima, H. 1987. Skeletal anomalies in a patient with the Pallister/Teschler-Nicola/Killian syndrome. Am. J. Med. Genet. 27: 285-289.

Kelly, T.E., Bruns, D.E., Mifflin, T.E., and Atkin, J.F. 1985. LD-B dose effect in tetrasomy 12p pseudomosaicism. Pediatr. Res. 19: 250 Abstract.

Ketupanya, A., Crandall, B.F., Blanchard, K., and Rogers, D.W. 1984. Mosaic hexasomy 21. J. Med. Genet. 21 : 228-230.

Kwee, M.L., Barth, P.G., Arwert, F., and Madan, K. 1984. Mosaic tetrasomy 21 in a male child. Clin. Genet. 26: 150-155.

Lopes, V., Mak, E., and Wyatt, P.R. 1985. Prenatal diagnosis of tetrasomy 21. Prenat. Diagn. 5: 233-235.

Lowry, O.H., Rosebrough, N.J., Farr, A.L., and Randall, R.J. 1951. Protein measurement with the Folin phenol reagent. J. Biol. Chem. 193: 265-275.

McCord, J.M. and Fridovich, I. 1969. Superoxide dismutase: An enzymic function for erythrocuprein (hemocuprein). J. Biol. Chem. 244: 6049-6055.

Pallister, P.D., Meisner, L.F., Elejalde, B.R., Francke, U., Herrmann, J., Spranger, J., Tiddy, W., Inhorn, S.L., and Opitz, J.M. 1977. The Pallister mosaic syndrome. Birth Defects 13: 103110.

Pauli, R.M., Zeier, R.A., and Sekhon, G.S. 1987. Mosaic tetrasomy 12p. Am. J. Med. Genet. 27: 291-294.

Peltomäki, P., Knuutila, S., Ritvanen, A., Kaitila, I., and de la Chapelle, A. 1987. Pallister-Killian syndrome: Cytogenetic and molecular studies. Clin. Genet. 31: 399-405.

Raffel, L.J., Mohandas, J.T., and Rimoin, D.L. 1986. Chromosomal mosaicism in the Killian/ Teschler-Nicola syndrome. Am. J. Med. Genet. 24; 607-611.

Reynolds, J.F., Daniel, A., Kelly, T.E., Gollin, S.M., Stephan, M.J., Carey, J., Adkins, W.N., Webb, M.J., Char, F., Jimenez, J.F., and Opitz, J.M. 1987. Isochromosome 12p mosaicism (Pallister mosaic aneuploidy or Pallister-Killian syndrome): Report of 11 cases. Am. J. Med. Genet. 27: 257-274.

Steinbach, P. and Rehder, H. 1987. Tetrasomy for the short arm of chromosome 12 with accessory isochromosome $(+\mathrm{i}(12 \mathrm{p}))$ and a marked LDH-B gene dosage effect. Clin. Genet. 32: 1-4.

Teschler-Nicola, M. and Killian, W. 1981. Case report 72: Mental retardation, unusual facial appearance, abnormal hair. Synd. Ident. 7: 6-7.

Van Dyke, D.L., Babu, V.R., and Weiss, L. 1987. Parental age, and how extra isochromosomes (secondary trisomy) arise. Clin. Genet. 32: 75-80.

Vine, D.T., Kaffe, S., Arrendondo-Vega, F., Desnick, R.J., and Smith, M. 1984. Teschler-Nicola/ Killian syndrome and mosaic tetrasomy 12p. To the editor. J. Clin. Dysmorphol. 2: 7.

Warburton, D., Anyane-Yeboa, K., and Francke, U. 1987. Mosaic tetrasomy 12p: Four new cases, and confirmation of the chromosomal origin of the supernumerary chromosome in one of the original Pallister-Mosaic syndrome cases. Am. J. Med. Genet. 27: 275-283.

Wroblewski, F. and La Due, J.S. 1955. Lactic dehydrogenase activity in blood. Proc. Soc. Exp. Biol. Med. 90: 210-213. 